\title{
DESAIN MODEL GUIDED INQUIRYUNTUK EKSPLORASI KESULITAN BELAJAR DAN PENGARUHNYA TERHADAP HASIL BELAJAR SERTA KETERAMPILAN PEMECAHAN MASALAH
}

\author{
Betty Marisi Turnip dan Mariati Purnama Simanjuntak \\ Jurusan Fisika FMIPA Universitas Negeri Medan \\ ibeth.toernip@gmail.com
}

\begin{abstract}
ABSTRAK
Desain penelitian ini bertujuan untuk mengeksplorasi kesulitan belajar yang dialami mahasiswa serta pengaruhnya terhadap hasil belajar dan keterampilan pemecahan masalah pada pokok bahasan Kinematika dan Dinamika Partikel melalui model pembelajaran guided inquiry. Analisis kebutuhan dilakukan melalui studi literatur dan studi lapangan. Metode yang digunakan dalam penelitian ini adalah kuasi-eksperimen dengan pretest-posttest control group design. Instrumen untuk mengeksplorasi kesulitan belajar menggunakan angket. Instrumen tes hasil belajar berbentuk pilihan berganda dengan lima option. Instrumen tes keterampilan pemecahan masalah berbentuk uraian yang sudah divalidasi.
\end{abstract}

Kata kunci : model pembelajaran guided inquiry, eksplorasi kesulitan belajar, hasil belajar dan keterampilan pemecahan masalah

\section{PENDAHULUAN}

Fisika sebagai bagian dari pendidikan sains yang merupakan salah satu ilmu, yang sangat berperan penting dalam upaya penguasaan ilmu dan teknologi. Kemajuan ilmu dan teknologi menuntut seseorang untuk dapat menguasai informasi dan pengetahuan, termasuk di dalamnya Fisika Umum. Fisika Umum merupakan ilmu pengetahuan tentang fenomena alam, berupa kumpulan fakta, konsep, prinsip, teori dan hukum serta proses yang sistematis yang dapat diuji kebenarannya. Fisika Umum mendasari fisika lanjut dan rekayasa yang berdasarkan hasil observasi fenomena, pengukuran yang tepat, interaksi yang luas dengan peralatan dan eksperimen yang luas dan mendalam.

Berdasarkan hasil pengalaman peneliti mengajar Fisika Umum di salah satu universitas di Medan ditemukan beberapa permasalahan, di antaranya pembelajaran yang masih didominasi dosen dengan metode yang dominan adalah ceramah, tanya jawab dan penugasan. Proses pembelajaran cenderung terbatas pada aspek hafalan dan latihan soal yang lebih menekankan penerapan rumusrumus secara matematis sehingga mahasiswa yang lemah matematika akan merasa kesulitan untuk 
belajar fisika. Hal ini didukung dari hasil studi pendahuluan yang dilakukan pada 47 mahasiswa calon guru fisika pada salah satu perguruan tinggi negeri di Medan memperlihatkan mahasiswa mempersepsikan fisika sebagai terlalu banyak rumus (85\%), materi terlalu rumit (85\%), sulit dihafalkan (64\%), dan membutuhkan perhitungan yang rinci (70\%) (Simanjuntak, 2012). Dengan kondisi tersebut menyebabkan hasil belajar fisika mahasiswa menjadi rendah, khususnya Fisika Umum. Rendahnya hasil belajar juga disebabkan karena mahasiswa merasa kesulitan dalam hal menulis, memahami bacaan, menerapkan rumus matematis, memecahkan masalah dan memberi perhatian.

$\begin{array}{ccc}\text { Selain } & \text { upaya } & \text { untuk } \\ \text { meningkatkan } & \text { hasil belajar, }\end{array}$ mahasiswa juga perlu dibekali kemampuan beradaptasi yang tinggi, keterampilan pemecahan masalah, dan kemampuan untuk bertahan hidup. Perkuliahan Fisika Umum dapat berperan dalam melatihkan kemampuan beradaptasi dan keterampilan pemecahan masalah bagi calon guru fisika. Upaya melatihkan keterampilan pemecahan masalah pada perkuliahan fisika sebenarnya merupakan keharusan. Giancoli (2001) menyatakan bahwa pemecahan masalah merupakan bagian dasar dari perkuliahan fisika dan keterampilan pemecahan masalah itu sendiri merupakan keterampilan yang sangat berguna karena proses tersebut membawa pemahaman terhadap fisika yang lebih mendalam. Dalam kerangka penyiapan calon guru fisika yang memiliki keterampilan pemecahan masalah, upaya yang dapat dilakukan adalah mendorong mahasiswa untuk memperdalam konsep-konsep fisika melalui kegiatan pemecahan masalah.

Keterampilan pemecahan masalah yang dikembangkan dalam Fisika Umum dalam konteks ini, berupa proses yang dilalui seseorang untuk memperoleh jawaban terhadap suatu masalah, yaitu kemampuan mengaplikasi konsepkonsep fisika dalam permasalahan yang berkaitan dengan kehidupan sehari-hari.

Salah satu cara yang digunakan untuk mengatasi permasalahan tersebut adalah dengan menerapkan model pembelajaran inkuiri terbimbing (guided inquiry). Dengan menggunakan model pembelajaran ini diharapkan dapat mendorong mahasiswa untuk berpikir sendiri, berdiskusi dan menganalisis dalam tahap-tahap penyajian masalah, pengumpulan data, pelaksanaan eksperimen, pengorganisiran data dan perumusan penjelasan sehingga dapat menemukan konsep berdasarkan bahan atau data yang disediakan dosen. Dengan menerapkan model inkuiri terbimbing memungkinkan mahasiswa untuk berusaha memecahkan masalah yang dihadapinya sehingga mereka lebih aktif dan lebih membantu dalam memahami konsep fisika sehingga mencapai hasil belajar dan keterampilan pemecahan masalah yang lebih baik (Panasan \& Nuangchalerm, 2010).

Penerapan model guided inquiry juga diharapkan dapat mengatasi kesulitan belajar 
mahasiswa (Nuangchalerm \& Thammasena, 2009 dan Wijayanti, dkk., 2010). Kesulitan belajar adalah hal-hal yang dapat mengakibatkan kegagalan atau setidak-tidaknya menjadi gangguan yang bisa menghambat kemajuan belajar (Aro, et all., 2011 dan Hamalik, 1990). Menurut Aro, et all., (2011) yang termasuk dalam kesulitan belajar adalah dalam hal menulis, memahami bacaan, menerapkan rumus matematis, memecahkan masalah dan memberi perhatian.

\section{METODE PENELITIAN}

Metode yang digunakan dalam penelitian ini adalah kuasieksperimen dengan pretest-posttest control group design. Sampel dalam penelitian ini terdiri dari dua kelas yang ditentukan secara acak (cluster random sampling). Kelas eksperimen dengan menggunakan model pembelajaran guided inquiry dan kelas kontrol menggunakan model pembelajaran tradisional.

Instrumen yang digunakan pada penelitian ini didasarkan atas data yang diperlukan. Instrumen yang digunakan dalam penelitian ini berupa lembar observasi, instrumen kesulitan belajar, tes hasil belajar, tes keterampilan pemecahan masalah, angket dan wawancara. Instrumen kesulitan belajar berupa angket yang terdiri dari 40 pernyataan-pernyataan. Instrumen tes hasil belajar yang dirancang berjumlah 60 soal. Instrumen pemecahan masalah berjumlah 14 soal.

Data yang diperoleh pada penelitian ini terdiri atas data kualitatif dan data kuantitatif. Data kuantitatif berupa skor kesulitan belajar, hasil observasi, angket dan wawancara yang dianalisis dengan secara deskriptif. Data kuantitatif berupa skor tes hasil belajar dan keterampilan pemecahan masalah yang dianalisis dengan menggunakan statistik inferensial.

Efektivitas

model

pembelajaran terhadap peningkatan hasil belajar dan keterampilan pemecahan masalah berdasarkan persentase gain yang dinormalisasi (N-gain). Perbedaan hasil belajar dan keterampilan pemecahan masalah antara kelompok eksperimen dan kontrol dianalisis dengan menggunakan uji beda (ujit).

Sintaks model pembelajaran guided inquiry yang digunakan dalam penelitian ini mengacu pada (Kuhlthau, et al., 2012) seperti ditunjukkan pada Tabel 1 .

Tabel 1. Sintak Model Pembelajaran Guided Inquiry

\begin{tabular}{|c|l|l|}
\hline No & \multicolumn{1}{|c|}{ Sintaks } & \multicolumn{1}{|c|}{ Kegiatan Dosen } \\
\hline 1 & orientasi & $\begin{array}{l}\text { Mengorientasikan } \\
\text { mahasiswa belajar }\end{array}$ \\
\hline 2 & eksplorasi & $\begin{array}{l}\text { Membimbing } \\
\text { mahasiswa } \\
\text { melakukan } \\
\text { penyelidikan }\end{array}$ \\
\hline 3 & identifikasi & $\begin{array}{l}\text { Membimbing } \\
\text { mahasiswa } \\
\text { mengidentifikasi } \\
\text { hasil penyelidikan }\end{array}$ \\
\hline 5 & aplikasi & $\begin{array}{l}\text { Membimbing } \\
\text { mahasiswa } \\
\text { membentuk konsep }\end{array}$ \\
\hline 6 & Evaluasi & $\begin{array}{l}\text { Membimbing } \\
\text { mahasiswa } \\
\text { mengaplikasikan } \\
\text { hasil penyelidikan }\end{array}$ \\
\hline $\begin{array}{l}\text { Mengevaluasi hasil } \\
\text { mahelidikan }\end{array}$ \\
\hline
\end{tabular}




\section{HASIL DAN PEMBAHASAN}

\section{Hasil Penelitian}

Berdasarkan studi pendahuluan melalui pengalaman dan pengamatan di lapangan, proses belajar mengajar Fisika Umum di kelas lebih menekankan penggunana rumus-rumus matematis dalam menyelesaikan soal-soal. Metode yang digunakan dominan ceramah dan tanya jawab. Masalah yang diberikan dosen berupa soal-soal yang ada di buku sumber yang lebih menekankan pada manipulasi matematis, bukan masalah konstektual yang ada dalam kehidupan sehari-hari. Mahasiswa yang lemah matematika akan semakin sulit belajar fisika.

Berdasarkan hasil wawancara, dosen belum pernah menggunakan model yang dapat mengeksploitasi kesulitan belajar dan meningkatkan hasil belajar serta keterampilan pemecahan masalah secara khusus.

Berkaitan dengan sumber belajar, umumnya mahasiswa menggunakan buku ajar yang dibuat oleh tim dosen Fisika Umum sebagai sumber buku utama. Menurut mereka, buku ini merupakan buku pegangan dosen yang digunakan dalam perkuliahan, materinya diramu dari beberapa sumber. Selain buku ajar, mahasiswa juga memanfaatkan buku-buku teks yang tersedia di perpustakaan lembaga.

\section{Berdasarkan}

analisis kebutuhan mahasiswa, kondisi perkuliahan Fisika Umum, sumber belajar dan fasilitas, dan analisis kemampuan mahasiswa, maka salah satu tujuan yang hendak dicapai dalam perkuliahan Fisika Umum adalah untuk mengekploitasi kesulitan belajar, meningkatkan hasil belajar dan keterampilan pemecahan masalah mahasiswa.

Indikator kesulitan belajar yang dikembangkan dalam hal menulis, memahami bacaan, menerapkan rumus matematis, memecahkan masalah dan memberi perhatian (Aro, et all., 2011)
Indikator hasil belajar yang dikembangkan adalah mengingat, memahami, mengaplikasikan, menganalisis, mengevaluasi dan mencipta (Anderson dan Krathwol, 2001).

Indikator keterampilan pemecahan masalah adalah mengenali masalah, mendeskribsikan masalah, merencanakan solusi, melakukan apa yang direncanakan dan mengevaluasi solusi (Heller \& Heller, 2010).

Adapun instrumen kesulitan belajar yang dikembangkan terdiri dari 40 pernyataan. Angket untuk mengukur kesulitan belajar dibuat secara terstruktur berupa pernyataan-pernyataan dengan menggunakan skala Likert. Instrumen kesulitan belajar ditunjukkan pada Tabel 2 .

Tabel 2. Aspek Kesulitan Belajar

\begin{tabular}{|c|l|c|}
\hline No & $\begin{array}{c}\text { Aspek Kesulitan } \\
\text { Belajar }\end{array}$ & $\begin{array}{c}\text { Jumlah } \\
\text { Pernyataan }\end{array}$ \\
\hline 1 & membaca & 4 \\
\hline 2 & menulis & 6 \\
\hline 3 & memahami bacaan & 9 \\
\hline 4 & $\begin{array}{l}\text { menerapkan } \\
\text { rumus matematis }\end{array}$ & 4 \\
\hline 5 & $\begin{array}{l}\text { memecahkan } \\
\text { masalah }\end{array}$ & 6 \\
\hline 6 & $\begin{array}{l}\text { memberi } \\
\text { perhatian }\end{array}$ & 11 \\
\hline \multicolumn{2}{|c|}{ Total } & 40 \\
\hline
\end{tabular}

Berdasarkan hasil studi pendahuluan, dengan memberikan angket kesulitan belajar kepada 36 mahasiswa didapat hasil seperti ditunjukkan pada Tabel 3 . 
Tabel 3. Rekapitulasi Hasil Ujicoba Angket Kesulitan Belajar

\begin{tabular}{|l|c|c|c|}
\hline $\begin{array}{c}\text { Aspek } \\
\text { Kesulitan } \\
\text { Belajar }\end{array}$ & $\begin{array}{c}\text { Rerat } \\
\text { a }\end{array}$ & $\begin{array}{c}\text { Kesulit } \\
\text { an } \\
\text { Belajar }\end{array}$ & Kategori \\
\hline membaca & 2,83 & 70,66 & baik \\
\hline menulis & 2,72 & 68,06 & cukup \\
\hline $\begin{array}{l}\text { memahami } \\
\text { bacaan }\end{array}$ & 2,54 & 63,43 & cukup \\
\hline $\begin{array}{l}\text { menerapkan } \\
\text { rumus } \\
\text { matematis }\end{array}$ & 2,51 & 62,85 & cukup \\
\hline $\begin{array}{l}\text { memecahkan } \\
\text { masalah }\end{array}$ & 2,40 & 60,09 & cukup \\
\hline $\begin{array}{l}\text { memberi } \\
\text { perhatian }\end{array}$ & 2,61 & 65,34 & cukup \\
\hline
\end{tabular}

Keterangan kategori: Sangat baik (85-100\%); Baik (70-84\%); Cukup (55 - 69\%); Kurang (40 - 54\%); dan Sangat kurang (0 - 39\%)

\section{Pembahasan}

Aspek kesulitan yang dihadapi mahasiswa yang paling rendah diurutan pertama adalah dalam hal memecahkan masalah, dalam kategori cukup. Berdasarkan hasil penelitian diperoleh mahasiswa yang mengalami kesulitan dalam memecahkan masalah sebesar 60,09\%. Jika dari $100 \%$ yang mengalami kesulitan dalam memecahkan masalah fisika sebanyak 60,09\%, maka persentase mahasiswa yang tidak mengalami kesulitan dalam memecahkan masalah fisika sebanyak 39,91\%.

$$
\text { Aspek kesulitan yang }
$$

dihadapi mahasiswa yang paling rendah diurutan kedua adalah dalam hal menerapkan rumus matematis dalam pembelajaran fisika, dalam kategori cukup. Berdasarkan hasil penelitian diperoleh mahasiswa yang mengalami kesulitan dalam menerapkan rumus matematis sebesar 62,85\%. Jika dari 100\% yang mengalami kesulitan dalam menerapkan rumus matematis dalam pembelajaran fisika sebanyak $62,85 \%$, maka persentase mahasiswa yang tidak mengalami kesulitan dalam menerapkan rumus matematis sebanyak $37,15 \%$.

Aspek kesulitan yang dihadapi mahasiswa yang paling rendah diurutan ketiga adalah dalam hal memahami bacaan, dalam kategori cukup. Berdasarkan hasil penelitian diperoleh mahasiswa yang mengalami kesulitan dalam memahami bacaan yang berkaitan dengan materi fisika, yaitu sebesar $63,43 \%$. Jika dari 100\% yang mengalami kesulitan dalam memahami bacaan sebanyak 63,43\%, maka persentase mahasiswa yang tidak mengalami kesulitan dalam memahami bacaan yang berkaitan dengan materi fisika sebanyak $36,57 \%$.

Aspek kesulitan yang dihadapi mahasiswa yang paling rendah diurutan keempat adalah dalam hal memberi perhatian saat belajar fisika, dalam kategori cukup. Berdasarkan hasil penelitian diperoleh mahasiswa yang mengalami kesulitan dalam memberi perhatian saat belajar fisika, yaitu sebesar 65,34\%. Jika dari $100 \%$ yang mengalami kesulitan dalam memahami bacaan sebanyak $65,34 \%$, maka persentase mahasiswa yang tidak mengalami kesulitan dalam memecahkan masalah fisika sebanyak $34,66 \%$.

Aspek kesulitan yang dihadapi mahasiswa yang paling rendah diurutan kelima adalah dalam hal menulis hal-hal yang berkaitan dengan fisika, dalam kategori cukup. Berdasarkan hasil penelitian diperoleh mahasiswa 
yang mengalami kesulitan dalam menulis hal-hal yang berkaitan dengan fisika, yaitu sebesar $68,06 \%$. Jika dari $100 \%$ yang mengalami kesulitan dalam sebanyak $68,06 \%$, maka persentase mahasiswa yang tidak mengalami kesulitan dalam menulis hal-hal yang berkaitan dengan fisika sebanyak $31,94 \%$.

Berdasarkan enam aspek kesulitan belajar yang dikembangkan dan diukur dalam penelitian ini, aspek memecahkan masalah fisika yang dirasa paling sulit karena mahasiswa dalam proses pembelajaran tidak terbiasa dilatih dalam memecahkan masalah yang berkaitan dalam kehidupan sehari-hari sehingga saat menghadapi masalah, mereka merasa kesulitan untuk mencari solusinya.

Kesulitan belajar yang dialami mahasiswa diurutan kedua dalam hal menerapkan rumus matematis. Ini terjadi karena dalam belajar fisika, banyak rumus matematis yang harus diturunkan dan digunakan dalam penyelesaian soal-soal fisika. Banyaknya rumus yang diturunkan dan digunakan membuat mahasisa kesulitan untuk mengaplikasikan rumus tersebut secara tepat.

Hasil penelitian ini didukung oleh Wijayanti, dkk., (2010) yang mana hasil penelitiannya dengan menerapkan model guided inquiry pada pembalajaran di SMP di kelas eksperimen dapat mengurasi kesulitan belajar, dimana persentase kesulitan belajar siswa dalam hal memahami materi (17\%), mengaitkan hubungan antar konsep (19\%), mengerti rumus (30\%) dan mengoperasikan rumus untuk menyelesaikan soal-soal (43\%). Di kelas kontrol yang menerapkan pembelajaran konvensional, persentase kesulitan belajar dalam hal memahami materi (21\%), mengaitkan hubungan antar konsep (35\%), mengerti rumus (34\%) dan mengoperasikan rumus untuk menyelesaikan soal-soal (47\%).

Kesulitan-kesulitan belajar yang dialami mahasiswa akan menghambat prestasi belajar mereka. Hal ini didukung oleh Hamalik (1990) yang menyatakan bahwa hal-hal yang bisa mengakibatkan kegagalan atau setidak-tidaknya menjadi gangguan yang bisa menghambat kemajuan belajar. Dalam hal ini siswa mengalami kesulitan dalam mengoperasikan rumus untuk menyelesaikan soal siswa harus mempunyai empat kategori kemampuan kognitif sekaligus yaitu kemampuan C3 (aplikasi rumus), kemampuan C4 (analisis rumus yang digunakan), kemampuan C5 (sintesis), dan kemampuan C6 (evaluasi), sehingga banyak siswa yang mengalami kesulitan. Pada umumnya siswa kesulitan dalam berhitung dan analisis matematika, sebenarnya hal ini dapat diatasi dengan sering memberikan latihan soal sebagai evaluasi pada setiap akhir pembelajaran, sehingga siswa terbiasa menghadapi soal dan memecahkannya dengan informasi pengetahuan yang dimilikinya.

Hal ini sesuai dengan pendapat Gonzales \& Stone (2007) bahwa siswa yang mengalami kesulitan dalam belajar fisika dengan indikasi nilai yang rendah dan di bawah rata-rata perlu diberikan pembelajaran yang dapat lebih membuat para siswa memahami apa 
yang dipelajari dengan melakukan praktek secara langsung dengan bimbingan dari guru, karena dengan melakukan siswa lebih memiliki interaksi langsung dengan pengetahuan yang dia pelajari.

Kegiatan seperti ini juga akan membawa kemampuan kognitif siswa menjadi lebih baik dan berarti, karena siswa menjadi lebih aktif dalam memperoleh pengetahuan melalui pengalaman langsung, dan bukan hanya sekedar mendengar dan menerima pengetahuan atau informasi dari apa yang dikatakan oleh guru saja.

\section{KESIMPULAN}

Kesimpulan yang didapat berdasarkan hasil penelitian yang telah dilakukan adalah sebagai berikut:

1. Telah dirancang model guided inquiry pada pembelajaran Fisika Umum pada topik Kinematika dan Dinamika Partikel untuk mengeksploitasi kesulitan belajar dan meningkatkan hasil belajar serta keterampilan pemecahan masalah.

2. Indikator kesulitan beljar yang dikembangkan adalah dalam hal menulis, memahami bacaan, menerapkan rumus matematis, memecahkan masalah dan memberi perhatian.

3. Indikator hasil belajar yang dikembangkan adalah mengingat, memahami, mengaplikasikan, menganalisis, mengevaluasi, dan mencipta.

4. Indikator

keterampilan pemecahan masalah yang dikembangkan adalah mengenali masalah, mendeskribsikan masalah, merencanakan solusi, melakukan apa yang direncanakan dan mengevaluasi solusi.

\section{UCAPAN TERIMA KASIH}

$\begin{array}{lrr}\text { Terimakasih } & \text { yang } & \text { tulus } \\ \text { disampaikan } & \text { kepada } & \text { Dirjen }\end{array}$ Pendidikan Tinggi yang telah memberikan dana untuk mendukung pelaksanaan penelitian fundamental ini.

\section{DAFTAR PUSTAKA}

Aro, T. \& Aheren, T. (2011). Assessment of Learning Dissabilities Coorperation between Teacher, Psychologist and Parents. Learning and Learning Disabilities, African Edition.

Anderson, L.W, \& Krathwol, D.R. (eds). (2001). A Taxonomy for Learning Teaching and Assessing. A Revision of Bloom's Taxonomy of Educational Objectives.New York: Addison Wesley Longman, Inc.

Giancoli, D. C. (2001). Physics: Principles with Applications, Fifth Edition. New Jersey: Prentice Hall International.

Gonzales, W.J. \& Stone, M. 2007. Guiding Experiences in Physics Instruction for Undergraduates. Journal Physics Teaching Education Online 3(1).

Hamalik, O. (1990). Metoda Belajar dan Kesulitan Belajar. Bandung: Tarsito.

Heller, K. \& Heller, P. (2010). Cooperative Problem Solving in Physics A User's Manual. https://www.aapt.org/Conferenc es/.../Coop-Problem-SolvingGuide. 
Kuhlthau, C. C., Maniotes, L. K \& Caspari, A. K. (2012). Guided Inquiry Design: a Framework for Inquiry in You're School. ABC-CLIO: California.

Nuangchalerm, P. \& Thammasena, B. 2009. Cognitive Development, Analytical Thinking, and Learning Satisfaction of Second Grade Students learned through Inquiry based Learning. Journal of Asian Social Science 5(10): 82-87.

Panasan, M. \& Nuangchalerm, P. (2010). Learning Outcomes of Project-Based and Inquiry Based Learning Activities. Journal of Social Sciences $6(2): 252-255$.

Simanjuntak, M. P. (2012). Pengembangan Model Pembelajaran Fisika Dasar Berbasis Problem Solving untuk Meningkatkan Kemampuan Metakognisi dan Pemahaman Konsep Mahasiswa. Disertasi. Tidak dipublikasikan.

Wijayanti, P. I., Mosik, dan Hindarto, N. (2010). Eksplorasi Kesulitan Belajar Siswa pada Pokok Bahasan Cahaya dan Upaya Peningkatan Hasil Belajar Melalui Pembelajaran Inkuiri Terbimbing, Jurnal Pendidikan Fisika Indonesia. 6 (1-5) ISSN: 1693-1246. 